\title{
SUMARNI INVENTAR FONDA HR-DAPA-474 NARODNI ODBOR OPĆINE GROŽNJAN (COMITATO POPOLARE COMUNALE GRISIGNANA) [1951] 1952-1955
}

\author{
Vedran DUKOVSKI \\ Državni arhiv u Pazinu \\ Pazin, Vladimira Nazora 3 \\ vedran.dukovski@dapa.hr
}

\author{
UDK 930.253:352.9 \\ (497.571Grožnjan)“1952/1955“ \\ Stručni rad \\ https://doi.org/10.31726/via.26.26.6
}

\begin{abstract}
Arhivski fond HR-DAPA-474 Narodni odbor općine Grožnjan (Comitato popolare comunale Grisignana) [1951] 1952-1955 obuhvaća gradivo nastalo djelovanjem ovoga izvršnog tijela, dok se predspisi odnose na rad njegova prednika, Mjesnoga narodnog odbora Grožnjan, u navedenom razdoblju. Gradivo fonda sačuvano je fragmentarno, ali unatoč tome vrlo zorno svjedoči o radu NOO-a Grožnjan. Fond je arhivistički obrađen 2018. kada je izrađen i sumarni inventar. U opisu fonda korišten je višerazinski sustav arhivističkoga opisivanja kako bi se pružilo što više informacija o gradivu koje se nalazi u fondu i na taj način olakšalo pretragu korisnicima. Sumarni inventar također sadrži podatke o općem kontekstu djelovanja stvaratelja.
\end{abstract}

Ključne riječi: Narodni odbor općine Grožnjan, arhivski fond, sumarni inventar, Istra

Keywords: People's Committee of the Municipality of Grožnjan, archival fonds, summary inventory, Istria

Parole chiave: Comitato popolare comunale di Grisignana, fondo archivistico, inventario sommario, Istria

\section{ARHIVISTIČKI OPIS FONDA HR-DAPA-474 NARODNI ODBOR OPĆINE GROŽNJAN (Comitato popolare comunale Grisignana) [1951] 1952-1955}

\section{IDENTIFIKACIJA}

\section{Identifikacijska oznaka/signatura}

HR-DAPA-474 
Naslov

Narodni odbor općine Grožnjan

\section{Usporedni naziv}

Comitato popolare comunale Grisignana

Vrijeme nastanka gradiva

[1951] 1952-1955

Razina opisa

Fond

Količina i nosač jedinice opisa

5 knjiga, 8 kutija, $0,8 \mathrm{~d} / \mathrm{m}$

\section{KONTEKST}

\section{UPRAVNA POVIJEST STVARATELJA I POVIJEST FONDA}

\section{Stvaratelj}

Narodni odbor općine Grožnjan

\section{Normirani oblik naziva}

Narodni odbor općine Grožnjan

\section{Skraćeni naziv}

NOO Grožnjan

Razdoblje djelovanja stvaratelja

$1952-1955$

\section{Sjedište}

Grožnjan 


\section{Mjesna nadležnost}

Teritorijalna nadležnost NOO-a Grožnjan obuhvaćale je katastarske općine Grožnjan, dio katastarske općine Završje, dio katastarske općine Kostanjica i dio katastarske općine Kuberton s pripadajućim im naseljima. ${ }^{1}$

\section{Pravni položaj}

Tijelo državne uprave / jedinica lokalne razine.

\section{Povijest}

Narodni odbor općine (dalje: NOO) Grožnjan formiran je 25. 5. 1952. i preuzeo je funkciju i nadležnosti raspuštenoga mjesnog narodnog odbora Grožnjan, čiji je pravni sljednik. NOO Grožnjan ukinut je 1955. kada ulazi u sastav novoosnovanoga NOO-a Buje. ${ }^{2}$ Tijekom svojega postojanja djeluje unutar Narodnog odbora kotara (dalje: NOK) Buje, u koji još ulaze NOO Buje, NOO Umag, NOO Brtonigla, NOO Momjan i NOO Novigrad. ${ }^{3}$

\section{Djelatnost, funkcije}

Ovlasti i nadležnosti NOO-a definirane su Općim zakonom o narodnim odborima i Zakonom o narodnim odborima općina ${ }^{5}$. Ti su zakoni, u obliku Odluke o reorganizaciji narodnih odbora ${ }^{6}$ i Naredbe br. 30 o proširenju važnosti Zakona NR Hrvatske o narodnim odborima općina ${ }^{7}$, prošireni i na teritorij Vojne uprave Jugoslavenske armije (VUJNA), odnosno na Zonu B Slobodnoga teritorija Trsta (dalje: Zona B STT), na čijem je teritoriju djelovao i NOO Grožnjan. NOO-i tijela su državne vlasti, odnosno tijelo narodnoga samoupravljanja u općini. Oni su najviše tijelo državne vlasti općine i njima su podređena sva lokalna tijela uprave u općini. O svojoj su djelatnosti bili dužni izvještavati Narodni odbor kotara u sklopu kojega djeluju, u ovom slučaju narodni odbor kotara Buje. Njihova je nadležnost obuhvaćala jedno ili više mjesta koja su činila jedinstvenu geografsku cjelinu sa zajedničkim ekonomskim i kulturnim interesima. Na vlastitu inicijativu ili na prijedlog Zbora birača mogli su osnivati niže razine vlasti, odnosno seoske narodne odbore. Sve su

»Odluka o podjeli Istarskog okružja na kotareve i općine«, Službeni list Oblasnog narodnog odbora za Istru (dalje: SL IONO), 6/1952.

2 DAPA, HR-DAPA-474, NOO GROŽNJAN, 1952-1955, 2. Opće administrativno poslovanje (1952-1955), 2.2.1. Politika i postupci, Rješenje o pripojenju administrativno-teritorijalnog područja NOO-a Grožnjan budućoj Komuni Buje, dok. br. 290/55, 17. 3. 1955., kut. 3.; »Opći zakon o uređenju općina i kotara«, $S L$ FNRJ, 26/1955.; "Zakon o provođenju novog uređenja općina i kotara«, NN NRH, 33/1955.; »Zakon o nadležnosti narodnih odbora općina i kotara«, $N N, 38 / 1955$.

3 »Odluka o reorganizaciji narodnih odbora«, SL IONO, 6/1952.

$4 \quad$ „Opći zakon o Narodnim odborima«, Službeni list Federativne Narodne Republike Jugoslavije (dalje: SL FNRJ), 22/1952.

$5 \quad$ "Zakon o narodnim odborima općina«, Narodne novine Narodne Republike Hrvatske (dalje: NN NRH), $35 / 1952$.

6 »Odluka o reorganizaciji Narodnih odbora«, SL IONO, 6/1952.

7 »Naredba br. 30 o proširenju važnosti Zakona NR Hrvatske o narodnim odborima općina«, Službeni list Vojne uprave Jugoslavenske armije (dalje: SL VUJNA), 6/1952. 
poslove iz svoje nadležnosti obavljali na temelju i u granicama zakona i općih propisa viših državnih tijela, odnosno sukladno Ustavu i saveznim, odnosno republičkim zakonima. U jugoslavenskoj zoni STT-a djelovali su sukladno naredbama Vojne uprave jugoslavenske zone STT-a i odredbama NOK-a Buje i NOK-a Kopar, donesenima na temelju zakona i uredbi NRH, odnosno FNRJ.

Kao najviši predstavnici izvršne vlasti imali su zadaću osigurati nesmetano odvijanje privrednih, komunalnih, socijalnih i kulturnih radnji i procesa, nužnih za razvoj i boljitak općine. U njihovu nadležnost spadalo je samostalno donošenje budžeta, uvođenje lokalnog prireza i drugih dadžbina. Određivali su način korištenja kamenoloma, pašnjaka, šuma, pojilišta, držanja domaćih životinja i dr. Istovremeno su vršili zaštitu i čuvanje polja, vinograda i privatne imovine. Donosili su planove za izgradnju vodovodne mreže, melioraciju doline rijeke Mirne i za uvođenje električne energije. Upravljali su održavanjem, bunara, česmi, cisterni, pojilišta i sl. Jednako tako donosili su planove za uređenje mjesta, izgradnju i obnovu. Održavali su stambeni fond i nadzirali njegovo korištenje. Upravljali su općenarodnom imovinom ukoliko ona nije pripadala drugim državnim organima, ustanovama i sl. Brinuli su o izvršavanju propisa o obvezatnom školovanju, jednako kao i o smještaju nastavnika i opremanju školskih zgrada. Poduzimali su mjere za sprječavanje i suzbijanje raznih bolesti, odnosno provodili su redovna cijepljenja. Brinuli su i skrbili za siromašne stanovnike, samohrane majke i djecu. Vršili su nadzor nad izvršavanjem zakona i drugih važećih propisa, prije svega nad upravnim i administrativno-kaznenim postupkom.

Predsjednik NOO-a predstavljao je NOO i zastupao općinu kao pravnu osobu. Njegova je dužnost bila briga o izvršenju odluka, mjera i propisa općine, ali i viših tijela vlasti. Predsjednik NOO-a sazivao je, pripremao i predsjedao sjednicama NOO-a, vodio brigu o zakonitu i pravilnu poslovanju tijela NOO-a i usklađivanju njihova rada s drugim tijelima. Utvrđivao je prijedlog proračuna i završnoga računa jednako kao što je bio i naredbodavac za izvršenje proračuna. Nadzirao je rad službenika i radnika, jednako kao što je nadgledao rad savjeta i komisija. Predsjednik je bio zadužen za potpisivanje svih akata NOO-a te je NOO-u podnosio izvještaje o radu svih tijela NOO-a, kao i njegove administracije. Za upravljanje administrativnim poslovima i radom službenika NOO-a bio je zadužen tajnik, koji je, pak, bio pod nadzorom predsjednika. Tajnika je, jednako kao i blagajnika i matičara, postavljao NOO, uz suglasnost predsjednika NOK-a. NOO-i su funkciju vlasti obavljali na svojim sjednicama. Sjednice su se održavale jednom mjesečno ili češće ako je to iziskivala situacija. Sjednice su mogle biti sazvane i na traženje odbornika (najmanje 1/5), odnosno savjeta ili komisije, i to najkasnije tri dana od podnošenja zahtjeva za sazivom. Zaključci sjednica donosili su se većinom glasova prisutnih odbornika, osim u slučaju da je zakonom ili statutom bilo propisano drugačije. Statut NOO-a donosio se i mijenjao većinom glasova svih odbornika. O radu sjednica vodili su se zapisnici koje je potpisivao predsjednik i dva ovjerovitelja, a dostavljali su se na uvid nadležnom NOK-u. NOO-i su mogli donositi pravne akte u obliku općih propisa (odluke, naredbe, uputstva). Naredbe i uputstva donosili su se temeljem ili radi provedbe općih propisa viših državnih tijela, ali i radi provedbe odluka samih NOO-a. NOO-i su funkciju državne uprave mogli obavljati i preko svojih savjeta i komisija koje su sami, prema potrebi, osnivali. Komisija za odluke, Komisija za molbe i 
žalbe te Mandatno-imunitetska komisija bile su stalne komisije, a uz njih NOO-i su imali pravo, prema potrebi, osnivati privremene komisije. Sve članove komisija birao je NOO iz redova odbornika. Komisije su za svoj rad odgovarale NOO-u kojemu su i podnosile izvještaj o radu. Statut NOO-a donosio je odrednice o sastavu, djelokrugu i načinu rada stalnih komisija. Rad, sastav i djelokrug privremenih komisija rješavao se aktom o njihovu osnivanju, a donosili su ga NOO-i. Osim komisija NOO-i su mogli osnivati i razne savjete koji su imali ulogu nadzora provedbe upravnih poslova. Savjeti su za svoj rad, jednako kao i komisije, odgovarali nadležnom NOO-u. Jednako tako, nadležnom NOO-u podnosili su izvještaj o radu i prijedloge za donošenje određenih propisa i mjera. Sastojali su se od predsjednika i još dva do šest članova. U slučaju NOO-a Grožnjan savjeti su se sastojali od predsjednika i još četiriju članova. Svi članovi Savjeta bili su dužni sudjelovati u njegovu radu, a nitko nije mogao biti član u više od dvaju savjeta. Svoje zaključke donosili su na sjednicama Savjeta. Savjeti su, kako bi si olakšali rad, mogli osnivati odbore koji su se bavili određenim pitanjima. U radu NOO-a sudjelovali su i građani koji su putem Zborova birača nadgledali rad NOO-a. Najmanje je dvaput godišnje NOO bio dužan Zborovima birača podnijeti na raspravu svoj Izvještaj o radu. Zborovi birača održavali su se, u pravilu, po selima i naseljima, ponajviše zbog razmatranja i predlaganja mjera za razvoj naselja, sela i općine. Jednako tako mogli su raspravljati i davati mišljenja i prijedloge koji su bili od značaja za život kotara, narodne republike i državne zajednice. Održavali su se prema potrebi, minimalno jednom u tri mjeseca. Sazivao ih je predsjednik NOO-a, na temelju zaključka NOO-a. Pravo sudjelovanja u radu imali su svi birači s područja u kojemu se Zbor održavao. O radu Zbora birača vodio se zapisnik.

\section{Nadležnosti/izvori ovlasti}

Rad, ustroj i nadležnosti narodnih odbora općina određeni su sljedećim zakonima, odlukama i naredbama iz 1952. i 1955. godine:

- Opći zakon o narodnim odborima (SL FNRJ, 22/1952)

- Opći zakon o uređenju općina i kotara (SL FNRJ, 26/1955)

- Zakon o narodnim odborima općina (NN NRH, 35/1952)

- Zakon o podjeli Narodne republike Hrvatske na kotare, gradove i općine (NN NRH, 16/1952)

- Zakon o narodnim odborima kotara $(N N N R H, 34 / 1952)$

- Zakon o provođenju novog uređenja općina i kotara (NN NRH, 33/1955),

- Zakon o području kotara i općina u Narodnoj Republici Hrvatskoj (NN, 36/1955)

- Zakon o nadležnosti narodnih odbora općina i kotara (NN, 38/1955)

- Odluka o reorganizaciji narodnih odbora (SL IONO, 6/1952)

- Odluka o podjeli Istarskog okružja na kotareve i općine (SL IONO, 6/1952)

- Naredba br. 3 o prenosu nadležnosti Istarskog Okružnog Narodnog Odbora na Kotarske Narodne Odbore Kopar i Buje (SL VUJNA, 3/1952) 
- Naredba br. 30 o proširenju važnosti Zakona NR Hrvatske o narodnim odborima općina (SL VUJNA, 6/1952)

- Naredba br. 34 o proširenju važnosti zakona NR Hrvatske o izboru i opozivu odbornika narodnih odbora (SL VUJNA, 6/1952).

\section{Unutarnji ustroj}

NOO-i, kao predstavničko tijelo naroda, birani su na tri godine tajnim glasovanjem, a birali su ih stanovnici općine, na temelju općega, jednakog i neposrednog izbornog prava. Sukladno tome bili su se dužni u svojemu radu oslanjati na inicijativu i uključenost narodnih masa i organizacija radnoga naroda. Brojevni sastav NOO-a određivao se njegovim statutom, a kod određivanja broja odbornika uzimala se u obzir veličina općine, broj stanovnika itd. Prema tome broj odbornika mogao je varirati od 11 do $35 .{ }^{8}$ NOO Grožnjan na početku svojega rada imao je 25 odbornika, da bi ih do trenutka kada prestaje s radom, imao 16. Organizacijski sastav NOO-a Grožnjan bio je sljedeći: predsjednik, tajnik, administracija, blagajna, matičar, izvršitelj, lugar i stražar. ${ }^{9}$ U sklopu NOO-a Grožnjan djelovali su sljedeći savjeti i komisije: Savjet za narodno zdravlje i socijalnu politiku, Savjet za privredu i komunalne poslove, Savjet za prosvjetu i kulturu, Komisija za odluke, Komisija za molbe i žalbe, Komisija za mandate i imunitete, Komisija za poreze, Komisija za izradu investicijskog plana, Komisija za prekršaje, Komisija za organizaciju i zakonodavstvo, Komisija za procjenu zasijanih uroda, Komisija za procjenu ostavine, Komisija za procjenu poljske štete, Komisija za odlikovanja, Komisija za radnu snagu pri NOO-u, Komisija za invalidninu, Komisija za izradu biračkih spiskova, Komisija za prikupljanje podataka, Komisija za izdavanje novih radnih knjižica, Komisija za (dječje) kolonije, Komisija za prodaju imovine odsutnih lica, Starateljski aktiv i Podkomisija za prikupljanje svih dokumenata radnika i službenika u poduzeću. Iz gradiva fonda vidi se kako je NOO Grožnjan formirao sedam seoskih narodnih obora (Grožnjan, Kostanjica, Bijele Zemlje, Martinčići, Poropati, Butori i Vrnjak) u kojima su se održavali Zborovi birača.

\section{Veze:}

\begin{tabular}{|l|l|l|}
\hline Prva veza \\
\hline $\begin{array}{l}\text { Naziv / oznaka } \\
\text { povezanog entiteta }\end{array}$ & Normirani oblik naziva & Mjesni narodni odbor Grožnjan \\
\cline { 2 - 3 } & Ostali oblici naziva & MNO Grožnjan \\
\hline Vrsta veze & Vremenska \\
\hline Opis veze & Prednik \\
\hline Nadnevci veze & $1947-1952$ \\
\hline
\end{tabular}

»Odluka o reorganizaciji narodnih odbora«, SL IONO, 6/1952.; »Zakon o narodnim odborima općina«, NN NRH, 35/1952.

9 DAPA, HR-DAPA-474, NOO GROŽNJAN, 1952-1955, 2. Opće administrativno poslovanje (1952-1955), 2.2.2. Izvještaj o radu i struktura NOO-a Grožnjan, dok. br. 732/55, 6. 7. 1955., kut. 3. 


\begin{tabular}{|l|l|l|}
\hline Druga veza \\
\hline $\begin{array}{l}\text { Naziv / oznaka } \\
\text { povezanog entiteta }\end{array}$ & Normirani oblik naziva & Mjesni narodni odbor Završje \\
\cline { 2 - 3 } & Ostali oblici naziva & MNO Završje \\
\hline Vrsta veze & Vremenska \\
\hline Opis veze & Prednik \\
\hline Nadnevci veze & $1947-1952$ \\
\hline
\end{tabular}

\begin{tabular}{|l|l|l|}
\hline \multicolumn{2}{|l|}{ Treća veza } \\
\hline $\begin{array}{l}\text { Naziv / oznaka } \\
\text { povezanog entiteta }\end{array}$ & Normirani oblik naziva & Narodni odbor općine Buje \\
\cline { 2 - 3 } & Ostali oblici naziva & NOO Buje \\
\hline Vrsta veze & Vremenska \\
\hline Opis veze & Slijednik \\
\hline Nadnevci veze & $1955-1965$ \\
\hline
\end{tabular}

\begin{tabular}{|l|l|l|}
\hline Četvrta veza \\
\hline \multirow{2}{*}{$\begin{array}{l}\text { Naziv / oznaka } \\
\text { povezanog entiteta }\end{array}$} & Normirani oblik naziva & Narodni odbor kotara Buje \\
\cline { 2 - 3 } & Ostali oblici naziva & NOK Buje \\
\hline Vrsta veze & Hijerarhijska \\
\hline Opis veze & Nadređeno tijelo \\
\hline Nadnevci veze & $1952-1955$ \\
\hline
\end{tabular}

\section{Povijest fonda}

Gradivo je nastalo djelovanjem stvaratelja, NOO-a Grožnjan. Do preuzimanja, 1977. gradivo se nalazilo kod sljednika, NOO-a Buje, a kasnije kod Skupštine općina Buje, od koje je preuzeto. Prva poznata obrada gradiva fonda napravljena je 1994. u DAPA-i, tada Povijesnom arhivu Pazin, kada je gradivo popisano. Tijekom sređivanja, 2018., gradivo je popisano, obavljen je odabir i napravljen je prijedlog za izlučivanje gradiva kojemu su istekli rokovi čuvanja. Prilikom sređivanja fonda gradivo je i tehnički opremljeno. Na samome kraju izrađen je sumarni inventar. Tijekom sređivanja fondu nije priključivano gradivo koje se čuvalo u drugim fondovima niti je iz ovoga fonda izdvojeno gradivo nekoga drugog fonda.

\section{Način preuzimanja ili predaje}

Primopredajni zapisnik nije sačuvan, a moguće da nije ni postojao. U Knjizi akvizicija vođenoj od 1964. do 2004. navodi se kako je gradivo fonda preuzimano po službenoj dužnosti od Skupštine općina Buje od 16. 9. do 11. 10. 1977., zajedno s gradivom drugih fondova s područja Bujštine. Dodatni podatci o preuzimanju, kao što su količina preuzetoga gradiva i raspon godina preuzetoga gradiva, nisu navedeni. 


\section{SADRŽAJ I USTROJ FONDA}

\section{Sadržaj}

Gradivo je nastalo djelovanjem stvaratelja, u razdoblju 1952. - 1955., i zorno prikazuje njegovo djelovanje i poslovanje s obzirom da se radi o upravnom tijelu. Fond sadrži zapisnike sjednica i materijale izvršne vlasti i pomoćnih tijela za čitavo vrijeme djelovanja stvaratelja. Na temelju sačuvanoga gradiva moguće je vrlo detaljno rekonstruirati kontekst vremena u kojemu stvaratelj djeluje. Jednako je tako sačuvano i gradivo nastalo svakodnevnim djelovanjem administracije, odnosno administrativnim poslovanjem. Tomu pripadaju okružnice, upute, preporuke, odluke, korespondencija s višim i nižim tijelima vlasti itd., a sve u svezi s rješavanjem aktualnih pitanja, problema i situacija koji su se po prirodi posla ticali stvaratelja. Osim spisa, fragmentarno su sačuvani urudžbeni zapisnici, kazala urudžbenih zapisnika, proračunske knjige, kontrolnici rashoda i izvadak iz stalnoga biračkog popisa. U spisima su, kao zasebna cjelina, sačuvani spisi Matičnoga ureda, koji je djelovao pri stvaratelju. Značajan dio gradiva odnosi se i na financijske spise. Gradivo fonda, općenito, detaljno svjedoči o svim aktivnostima stvaratelja, ali i principu poslovanja i djelovanja svih stvaratelja ovoga tipa u okviru zakonskih ovlasti.

\section{Odabiranje, izlučivanje i rokovi čuvanja}

Podatci o ranijem izlučivanju od strane stvaratelja ili imatelja ne postoje, a čini se da to nije učinjeno. Određeni su spisi zagubljeni zbog neodgovarajućeg rukovanja stvaratelja i njegovih sljednika.

Tijekom arhivističke obrade fonda određeni je dio gradiva izdvojen, popisan i predložen za izlučivanje. Za izlučivanje je predloženo gradivo kojemu su istekli rokovi čuvanja, sukladno Pravilniku vrednovanju te postupku odabiranja i izlučivanja arhivskog gradi$v a^{10}$. Popis gradiva predloženoga za izlučivanje napravljen je 2018. godine. Primjerci gradiva kojemu su istekli rokovi čuvanja (molbe, rješenja itd.), a istraživačima bi u budućnosti mogli olakšati rekonstrukciju svakodnevice na području NOO-a Grožnjan, nisu predloženi za izlučivanje. U tom se slučaju radi o manjoj količini spisa čiji sadržaj zorno ukazuje na životne prilike stanovništva, ali i neke nelogičnosti u funkcioniranju upravnoga aparata. Osim toga, u fondu postoji jedinica, 10.4, koju tek treba izlučiti u razdoblju 2022. - 2025.

\section{Dopune}

Ne predviđaju se daljnja preuzimanja gradiva. Moguće su dopune fonda gradivom pohranjenim u sklopu dosad neobrađenih fondova DAPA-e.

\section{Plan sređivanja}

Gradivo fonda zatečeno je osnovno sređeno i registraturno opremljeno. Bilo je pohranjeno u spremištu uz ostala poslijeratna tijela s područja NOK-a Buje. Registraturna pomagala bila su izdvojena od spisa i ne pokrivaju cijelo razdoblje djelovanja stvaratelja.

10 »Pravilnik o vrednovanju te postupku odabiranja i izlučivanja arhivskog gradiva«, $N N, 90 / 2002$. 
Prva je obrada ovoga fonda napravljena 1994., kada je gradivo popisano, ali je zadržan registraturni ustroj. S obzirom da je fond nastao prije 1958., odnosno prije stupanja na snagu Naredbe o planu jedinstvenih arhivskih znakova za sve organe uprave na teritoriju Narodne Republike Hrvatske ${ }^{11}$, većina se gradiva fonda sastojala od spisa odloženih u jedinstvenoj kronološkoj seriji. Izrađen popis gradiva nije pružao cjelovit uvid u sadržaj gradiva. Spisi su zadržani kao tzv. Opći spisi, u prvobitnom kronološkom redu, ustrojeni prema rastućem broju za svaku godinu.

Budući da je tako uspostavljen prvobitni red bio nedovoljno jasan u odnosu na poslove stvaratelja bilo je potrebno uspostaviti novu strukturu fonda. Tijekom sređivanja fonda osnovni su kriterij za oblikovanje nižih razina bili poslovi stvaratelja (djelomično podudarni s organizacijskim ustrojem) i sadržaj gradiva. Iznimku od ovih kriterija čini samo prva serija fonda koja sadrži zapisnike sastanaka raznih tijela NOO-a, koji su zbog svog značaja još od nastanka bili pohranjeni kao cjelina zasebna od ostatka fonda pa je takav prvobitni red i zadržan.

Razvrstavanjem općih spisa na odgovarajuće serije, s obzirom da su one odgovarale poslovima stvaratelja, odnosno pojedinim organizacijskim jedinicama naznačenima u sačuvanim urudžbenim zapisnicima (samo za 1952. - 1953.), stvoren je »ispravni prvobitni red«. Gradivo je prema potrebi razvrstano na podserije ili još niže razine radi lakšega služenja gradivom. Na svim je razinama složeno kronološki, prema datumu.

\section{DOSTUPNOST I KORIŠTENJE}

\section{Uvjeti dostupnosti i korištenja}

Fond ima status javnoga arhivskog gradiva i njegova je dostupnost regulirana Zakonom o arhivskom gradivu i arhivima ${ }^{12}$ i Pravilnikom o korištenju arhivskog gradiva ${ }^{13}$. Prema tome, javno arhivsko gradivo dostupno je od njegova nastanka ako zakonom nije određeno drugačije. Javno gradivo koje sadrži osobne podatke dostupno je 100 godina od rođenja osobe ili odmah nakon smrti osobe na koju se osobni podatci odnose. U slučaju da datum rođenja i smrti nisu poznati, dostupno je 70 godina od nastanka.

U serijama i podserijama napomenom označene one arhivske jedinice koje sadrže ovakvo gradivo, kao i godina kada navedeno gradivo postaje dostupno.

11 »Naredba o planu jedinstvenih arhivskih znakova za sve organe uprave na teritoriju Narodne Republike Hrvatske«, NN NRH, 7/1958.

12 »Zakon o arhivskom gradivu i arhivima«, $N N, 61 / 2018$.

13 »Pravilnik o korištenju arhivskog gradiva«, $N N, 67 / 1999$. 


\section{Uvjeti objavljivanja i umnožavanja}

Objavljivanje i umnožavanje gradiva regulirano je Zakonom o arhivskom gradivu $i$ arhivima, Pravilnikom o korištenju arhivskog gradiva i Pravilnikom o radu Čitaonice DAPA.

\section{Jezik i pismo}

Gradivo fonda pisano je latinicom (strojopis, rukopis). Većina je gradiva pisana hrvatskim jezikom. Određeni je dio gradiva pisan talijanskim jezikom, a samo nekoliko je dokumenata na slovenskom jeziku.

\section{Tvarne značajke i tehnički uvjeti}

Veći dio gradiva nastao je na uredskom papiru i tiskanim obrascima. Određeni dio nastao je na papiru iz blokova, bilježnica itd., koji su korišteni uslijed nedostatka uredskoga papira. S obzirom na neprimjerenu raniju pohranu i rukovanje, gradivo je u određenoj mjeri oštećeno. Oštećenja su mehaničke, biološke i fizikalno-kemijske naravi, nastala uslijed nepravilna rukovanja, pohrane, djelovanja vlage i Sunčeve svjetlosti. Bez obzira na spomenuta manja oštećenja, ne predlaže se restauracija. Tijekom sređivanja onda gradivo je tehnički opremljeno. Uklonjena je metalna oprema na gradivu, a zbog dodatne zaštite gradivo je smješteno u košuljice i pohranjeno u kutije. Dotrajala je oprema uklonjena i zamijenjena.

\section{Obavijesna pomagala}

RADALJAC, Ljiljana. HR-DAPA-474, Narodni odbor općine Grožnjan, 1952-1955, arhivski popis, DAPA, 1994.

DUKOVSKI, Vedran. HR-DAPA-474, Narodni odbor općine Grožnjan, 1952-1955, sumarni inventar, DAPA, 2018.

\section{DOPUNSKI IZVORI}

\section{Postojanje i mjesto čuvanja izvornika}

Izvornici se čuvaju u DAPA-i, na adresi Istarskoga razvoda 2, 52000 Pazin.

\section{Postojanje i mjesto čuvanja preslika}

Preslici fonda HR-DAPA-474, Narodni odbor općine Grožnjan, 1952-1955, ne postoje.

\section{Dopunski izvori}

HR-DAPA-504, Mjesni narodni odbor Grožnjan, 1948-1952.

HR-DAPA-82, Narodni odbor kotara Buje, 1945-1955. 
HR-DAPA-99, Narodni odbor općine Buje, 1955-1962.

HR-DAPA-816, Skupština općine Buje, 1963-1973.

\section{KONTROLA OPISA}

\section{Identifikator ustanove i opisa}

HR-DAPA-Obp-474/SI-1

\section{Pravila propisi}

Međunarodno arhivsko vijeće. ISAD (G) Međunarodna norma za opis arhivskog gradiva, 2. izd. (hrv. prijevod), Zagreb, 2001. Međunarodno arhivsko vijeće.

ISAAR (CPF) Međunarodna norma arhivističkog normiranog zapisa za pravne i fizičke osobe te obitelji, 2. izd. (hrv. prijevod), Zagreb, 2006.

$\mathrm{Za}$ potrebe kontekstualizacije povijesti korišten je element opisa Opći kontekst ISAAR(CPF).

\section{Napomena}

Gradivo fonda u cijelosti je popisao i sredio Vedran Dukovski, arhivist.

\section{Status}

Dovršen i dostupan opis.

\section{Razina podrobnosti}

Arhivistički je opis cjelovit.

\section{Nadnevci nastanka, izmjena i brisanja}

Obavijesno je pomagalo izrađeno 2018.

\section{Izvori:}

DAPA, HR-DAPA-474, Narodni odbor općine Grožnjan, 1952-1955.

Međunarodno arhivsko vijeće, ISAD (G) Međunarodna norma za opis arhivskog gradiva, 2. izd., Zagreb, 2001.

Međunarodno arhivsko vijeće, ISAAR (CPF) Međunarodna norma arhivističkog normiranog zapisa za pravne i fizičke osobe te obitelji, 2. izd., Zagreb, 2006.

Službeni list IONO, 6/1952.

Službeni list FNRJ, 22/1952. 
Službeni list FNRJ, 26/1955.

Službeni list VUJNA, 6/1952.

Narodne novine NRH, 35/1952.

Narodne novine NRH, 33/1955.

Narodne novine, NRH 38/1955.

Narodne novine NRH, 7/1958.

Narodne novine RH, 67/1999.

Narodne novine RH, 90/2002.

Narodne novine RH, 61/2018.

\title{
ARHIVISTIČKI OPISI I INVENTARNI POPISI NIŽIH RAZINA FONDA
}

\author{
1. ZAPISNICI I MATERIJALI IZVRŠNIH, POMOĆNIH \\ I NADZORNIH TIJELA NOO-a
}

\section{Signatura}

HR-DAPA-474/1

\section{Naslov}

Zapisnici i materijali izvršnih, pomoćnih i nadzornih tijela NOO-a

\section{Vrijeme nastanka gradiva}

1952-1955

\section{Razina opisa}

Serija

\section{Količina i zapis nosača}

1 kutija, $0,1 \mathrm{~d} / \mathrm{m}$

\section{Sadržaj}

Serija sadrži zapisnike i materijale izvršnih i nadzornih tijela. Serija obuhvaća zapisnike sjednica NOO Grožnjan, zapisnike i materijale Zbora birača, jednako kao i zapisnike Savjeta za prosvjetu i kulturu, Savjeta za privredu i komunalne poslove i Savjeta za narodno zdravstvo i socijalnu politiku. Serijom su obuhvaćeni i zapisnici Financijskoga odjela, 
Zapisnici porezne komisije i Zapisnici komisije za izradu investicijskoga plana. Na sjednicama se raspravljalo o aktualnim političkim, kulturnim, zdravstvenim, gospodarskim, komunalnim i drugim pitanjima neophodnima za poboljšanje kvalitete života stanovnika Općine.

\section{Plan sređivanja}

Gradivo serije razvrstano je na podserije i prema potrebi na podpodserije, unutar kojih je kronološki sređeno.

\section{Uvjeti dostupnosti}

Gradivo je serije javno arhivsko gradivo i prema Zakonu o arhivskom gradivu i arhivima i Pravilniku o korištenju arhivskog gradiva u potpunosti je dostupno. Ne sadrži osobne podatke zbog kojih bi pojedini dijelovi gradiva bili nedostupni.

\section{Inventarni popis gradiva serije}

\begin{tabular}{|c|c|c|c|c|}
\hline Signatura & Naslov/sadržaj & $\begin{array}{l}\text { Raspon } \\
\text { godina }\end{array}$ & $\begin{array}{l}\text { Tehnička } \\
\text { jedinica }\end{array}$ & Napomena \\
\hline \multicolumn{5}{|c|}{ 1. Zapisnici i materijali izvršnih, pomoćnih i nadzornih tijela NOO-a 1952-1955 } \\
\hline 1.1. & Zapisnici sjednica NOO Grožnjan & 1952-1955 & Kut. 1 & \\
\hline 1.2. & Zbor birača & $1952-1955$ & Kut. 1 & \\
\hline 1.2 .1 & Zapisnici Zbora birača & $1952-1955$ & Kut. 1 & \\
\hline 1.2 .2 . & Izvještaji o radu zborova birača & 1952 & Kut. 1 & \\
\hline 1.2.3. & $\begin{array}{l}\text { Izbor odbornika za Kotarsko vijeće i } \\
\text { Narodne odbore }\end{array}$ & 1952 & Kut. 1 & \\
\hline 1.2.4. & Izvadak iz stalnog biračkog spiska & 1952 & Kut. 1 & \\
\hline 1.3 . & $\begin{array}{l}\text { Savjet za prosvjetu i kulturu } \\
\text {-zapisnici }\end{array}$ & $1953-1954$ & Kut. 1 & \\
\hline 1.4. & Savjet za privredu i komunalne poslove & $1953-1955$ & Kut. 1 & \\
\hline 1.4.1. & $\begin{array}{l}\text { Zapisnici savjeta za privredu i komunalne } \\
\text { poslove }\end{array}$ & $1953-1954$ & Kut. 1 & \\
\hline 1.4 .2 & Zapisnici savjeta za privredu & $1953 / 1955$ & Kut. 1 & \\
\hline 1.4.3. & Zapisnici savjeta za komunalne poslove & 1953 & Kut. 1 & \\
\hline 1.5 & $\begin{array}{l}\text { Savjet za narodno zdravstvo i socijalnu } \\
\text { politiku } \\
\text {-zapisnici }\end{array}$ & $1953-1954$ & & \\
\hline 1.6. & Financijski odjel & $1953-1955$ & Kut. 1 & \\
\hline 1.6.1. & Zapisnici Financijskoga odjela & $1953 / 1955$ & & \\
\hline 1.6.2. & $\begin{array}{l}\text { Zapisnici sastanaka općinske porezne } \\
\text { komisije }\end{array}$ & 1954 & Kut. 1 & \\
\hline 1.6.3. & $\begin{array}{l}\text { Zapisnici komisije za izradu } \\
\text { investicijskoga plana }\end{array}$ & 1955 & Kut. 1 & \\
\hline
\end{tabular}




\section{OPĆE ADMINISTRATIVNO POSLOVANJE}

\section{Signatura}

HR-DAPA-474/2

Naslov

Opće administrativno poslovanje

\section{Vrijeme nastanka gradiva}

1952-1955

\section{Razina opisa}

Serija

\section{Količina i nosač zapisa}

4 knjige, $1 \frac{1}{2}$ kutija, $0,15 \mathrm{~d} / \mathrm{m}$

\section{Sadržaj}

Serija sadrži registraturna pomagala (urudžbeni zapisnici i kazala) i spise nastale administrativnim poslovanjem. Spisi iz ove serije prikazuju strukturu i rad stvaratelja te njegovu teritorijalnu nadležnost. Razne upute, dopisi, okružnice i ostali spisi svjedoče o administrativnom poslovanju i radu ovoga NOO-a. Zbog lakšega služenja gradivom i izbjegavanja dvostruke numeracije registraturna su pomagala (urudžbeni zapisnici i kazala urudžbenih zapisnika) smještena u kutiju.

\section{Plan sređivanja}

Gradivo serije razvrstano je na podserije i prema potrebi na podpodserije, unutar kojih je kronološki sređeno.

\section{Uvjeti dostupnosti i korištenja}

Dijelovi podserije 2.2 Općinska administracija koji sadrže osobne podatke dostupni su 100 godina od rođenja osobe ili nakon smrti osobe na koju se osobni podatci odnose. U slučaju da datumi rođenja i smrti nisu poznati, dostupno je 70 godina od nastanka. 
Inventarni popis gradiva serije

\begin{tabular}{|c|c|c|c|c|}
\hline Signatura & Naslov/sadržaj & \begin{tabular}{|l|} 
Raspon \\
godina
\end{tabular} & $\begin{array}{l}\text { Tehnička } \\
\text { jedinica }\end{array}$ & Napomena \\
\hline \multicolumn{5}{|c|}{ 2. Opće administrativno poslovanje 1952-1955 } \\
\hline 2.1. & Registraturna pomagala & $1952-1953$ & Kut. 2 & \\
\hline 2.1.1. & $\begin{array}{l}\text { Urudžbeni zapisnici } \\
\text { - Urudžbeni zapisnik br. 1-975 } \\
\text { - Urudžbeni zapisnik br. 1-2302 }\end{array}$ & $1952-1953$ & Kut. 2 & $\begin{array}{l}\text { Stari brojevi } \\
\text { knjiga: } 1 \text { i } 2\end{array}$ \\
\hline 2.1 .2 & $\begin{array}{l}\text { Kazala urudžbenih zapisnika } \\
\text { - kazalo urudžbenog zapisnika } 1952 \\
\text { - kazalo urudžbenog zapisnika } 1953\end{array}$ & $1952-1953$ & Kut .2 & $\begin{array}{l}\text { Stari brojevi } \\
\text { knjiga: } 3 \text { i } 4\end{array}$ \\
\hline 2.2. & Općinska administracija & $1952-1955$ & Kut. 3 & \\
\hline 2.2 .1 & Politika i postupci & $1952-1955$ & Kut. 3 & \\
\hline 2.2 .2 & $\begin{array}{l}\text { Izvještaji o radu i struktura NOO -a } \\
\text { Grožnjan }\end{array}$ & $1952-1953$ & Kut. 3 & \\
\hline 2.2 .3 & Imenovanja komisija i aktiva & $1952 / 1954$ & Kut. 3 & \\
\hline 2.2.4. & $\begin{array}{l}\text { Opći poslovi } \\
\text { - spisi predsjednika } \\
\text { - spisi tajnika } \\
\text { - upravljanje arhivskim gradivom } \\
\text { - inventari NOO-a }\end{array}$ & $1952-1955$ & Kut. 3 & \\
\hline 2.2 .5 & Personalni odsjek & $1952-1955$ & Kut. 3 & \\
\hline 2.2.5.1. & Polaganje stručnih ispita & 1952-1953 & Kut. 3 & \\
\hline 2.2.5.2. & Podatci o radnicima i namještenicima & $1952-1955$ & Kut. 3 & $\begin{array}{l}\text { Nedostupno do } \\
2037 .\end{array}$ \\
\hline 2.2.5.3. & Osobni dosjei & 1952 & Kut. 3 & $\begin{array}{l}\text { Nedostupno do } \\
2019 .\end{array}$ \\
\hline 2.2.5.4. & Natječaj za tajnika NOO-a & 1953 & Kut. 3 & \\
\hline
\end{tabular}

\section{UNUTRAŠNJI POSLOVI}

\section{Signatura}

HR-DAPA-474/3

\section{Naslov}

Unutrašnji poslovi

\section{Vrijeme nastanka gradiva}

[1951] 1952-1955 


\section{Razina opisa}

Serija

\section{Količina i zapis nosača}

1 knjiga, 1 kutija, $0,1 \mathrm{~d} / \mathrm{m}$

\section{Sadržaj}

Serija sadrži razne upute i okružnice koje se odnose na pitanje javne sigurnosti, iseljenja, preventivne mjere narodne obrane (protuavionska zaštita i DVD). U seriji se nalaze i spisi koji svjedoče o radu Matičnoga ureda NOO-a. Spisi Matičnog ureda odnose se na izvještaje o radu Matičnoga ureda, na statističke izvještaje o kretanju stanovništva (iseljeni/ useljeni) te na rođene, vjenčane i umrle. Spisi koji se odnose na umrle, sadrže obavijesti o smrti, postupke o proglašenju smrti i uvjerenja o smrti.

\section{Plan sređivanja}

Gradivo serije razvrstano je na podserije i prema potrebi na podpodserije, unutar kojih je kronološki sređeno.

\section{Uvjeti dostupnosti i korištenja}

Dijelovi podserija 3.4.5 Kretanje stanovništva, 3.4.6. Rođenja, 3.4.7. Vjenčani, 3.4.9. Osobni listovi sadrže osobne podatke i nedostupni su do isteka roka od 100 godina od rođenja osobe ili odmah nakon smrti osobe na koju se osobni podatci odnose. U slučaju da datumi rođenja i smrti nisu poznati, dostupno je 70 godina od nastanka.

\section{Inventarni popis gradiva serije}

\begin{tabular}{|l|l|l|l|l|}
\hline Signatura & Naslov/sadržaj & Raspon godina & $\begin{array}{l}\text { Tehnička } \\
\text { jedinica }\end{array}$ & Napomena \\
\hline \multicolumn{5}{|l|}{} \\
\hline 3. Unutrašnji poslovi [1951] 1952-1955 \\
\hline \multicolumn{5}{|l|}{} \\
\hline 3.1. & Politika i postupci & {$[1951] 1952-1955$} & Kut. 3 & \\
\hline 3.2. & Narodna obrana & $1953-1954$ & Kut. 3 & \\
\hline 3.3. & Dozvole za prijelaz granice & $1952-1953$ & Kut. 3 & \\
\hline 3.4. & Matični ured & {$[1951] 1952-1955$} & Kut. 3 & \\
\hline 3.4.1. & Politika i postupci & $1952-1954$ & Kut. 3 & \\
\hline 3.4.2. & $\begin{array}{l}\text { Urudžbeni zapisnik Matičnoga } \\
\text { ureda }\end{array}$ & {$[1951] 1952$} & Kut. 3 & \\
\hline
\end{tabular}




\begin{tabular}{|c|c|c|c|c|}
\hline 3.4.3. & $\begin{array}{l}\text { Izvještaji } \\
\text { - mjesečni izvještaji o radu } \\
\text { Matičnoga ureda } \\
\text { - statistički izvještaji } \\
\text { Matičnoga ureda } \\
\text { - Izvještaji o državljanima } \\
\text { FNRJ na području NOO-a } \\
\text { Grožnjan - dolasci/odlasci }\end{array}$ & [1951] 1952 & Kut. 3 & $\begin{array}{l}\text { Nedostaju } \\
\text { izvještaji } \\
\text { za kolovoz i } \\
\text { prosinac } 1952 .\end{array}$ \\
\hline 3.4 .4 . & Statistika broj stanovništva & 1952 & Kut. 3 & \\
\hline 3.4 .5 . & Kretanje stanovništva & $1952-1953$ & Kut. 3 & $\begin{array}{l}\text { Nedostupno do } \\
2041 \text {. }\end{array}$ \\
\hline 3.4.6. & Rođenja & [1951] 1952 & Kut. 3 & $\begin{array}{l}\text { Nedostupno do } \\
2034 \text {. }\end{array}$ \\
\hline 3.4.7. & Vjenčani & 1952 & Kut. 3 & $\begin{array}{l}\text { Nedostupno do } \\
2033 \text {. }\end{array}$ \\
\hline 3.4 .8 . & Umrli & [1951] 1952-1954 & Kut. 3 & \\
\hline 3.4.9. & Osobni listovi & $1952 / 1955$ & Kut. 3 & $\begin{array}{l}\text { Nedostupno do } \\
2052 \text {. }\end{array}$ \\
\hline
\end{tabular}

\section{VOJNI ODJEL}

\section{Signatura}

HR-DAPA-474/4

\section{Naslov}

Vojni odjel

\section{Vrijeme nastanka gradiva}

1954-1955

\section{Razina opisa}

Serija

\section{Količina i zapis nosača}

$0,01 \mathrm{~d} / \mathrm{m}$

\section{Sadržaj}

Serija sadrži spise nastale korespondencijom Vojnoga odjela i NOO-a, a odnosi se na upise u vojnu školu i podatke o vojnom zemljištu i zgradama na području NOO-a Grožnjan. U seriji se nalazi i 15 fotografija s 1. omladinskog logorovanja Narodne omladine Kotara Buje. 


\section{Plan sređivanja}

Gradivo unutar serije razvrstano je tematski.

\section{Uvjeti dostupnosti i korištenja}

Gradivo serije javno je arhivsko gradivo i prema Zakonu o arhivskom gradivu i arhivima i Pravilniku o korištenju arhivskog gradiva u potpunosti je dostupno. Ne sadrži osobne podatke zbog kojih bi pojedini dijelovi gradiva bili nedostupni.

Inventarni popis gradiva serije

\begin{tabular}{|l|l|l|l|l|}
\hline Signatura & Naslov/sadržaj & $\begin{array}{l}\text { Raspon } \\
\text { godina }\end{array}$ & $\begin{array}{l}\text { Tehnička } \\
\text { jedinica }\end{array}$ & Napomena \\
\hline \multicolumn{5}{|l|}{} \\
\hline \multicolumn{5}{|l|}{ 4. Vojni odjel 1954-1955 } \\
\hline \multicolumn{5}{|l|}{} \\
\hline 4.1. & Vojni objekti i zemljišta & 1954 & Kut. 4 & \\
\hline 4.2. & $\begin{array}{l}\text { Fotografije s 1. omladinskog logorovanja } \\
\text { Narodne omladine Kotara Buje }\end{array}$ & 1954 & Kut. 4 & (15 komada) \\
\hline 4.3. & Upisi u vojne škole & 1955 & Kut. 4 & \\
\hline
\end{tabular}

\section{PRAVOSUĐE}

\section{Signatura}

HR-DAPA-474/5

\section{Naslov}

Pravosuđe

\section{Vrijeme nastanka gradiva}

1952-1955

\section{Razina opisa}

Serija

\section{Količina i zapis nosača}

$0,02 \mathrm{~d} / \mathrm{m}$ 


\section{Sadržaj}

Serija sadrži spise (uputstva, okružnice itd.) koji se odnose na pravilno poslovanje sudova. U seriji se također nalaze i statistički izvještaji o radu suda, odnosno o prekršajima, odgodama izvršenja kazni i pomilovanja.

\section{Plan sređivanja}

Gradivo serije razvrstano je na podserije, unutar kojih je kronološki sređeno.

\section{Uvjeti dostupnosti i korištenja}

Dijelovi serije koji sadrže osobne podatke dostupni su 100 godina od rođenja osobe ili nakon smrti osobe na koju se osobni podatci odnose. U slučaju da datumi rođenja i smrti nisu poznati, dostupno je 70 godina od nastanka.

Inventarni popis gradiva serije

\begin{tabular}{|c|c|c|c|c|}
\hline Signatura & Naslov/sadržaj & Raspon godina & $\begin{array}{l}\text { Tehnička } \\
\text { jedinica }\end{array}$ & Napomena \\
\hline \multicolumn{5}{|c|}{ 5. Pravosuđe 1952-1955 } \\
\hline 5.1 & Politika i postupci & $1952-1953$ & Kut. 4 & \\
\hline 5.2 . & Statistički izvještaj o radu suda & $1952-1955$ & Kut. 4 & \\
\hline 5.3. & Prekršaji u svezi sa životinjama & $1953-1954$ & Kut. 4 & \\
\hline 5.4 . & $\begin{array}{l}\text { Prijave, pomilovanja i odgode } \\
\text { izvršenja kazni }\end{array}$ & $1953-1954$ & Kut. 4 & \\
\hline
\end{tabular}

\section{URED ZA STATISTIKU I EVIDENCIJU}

\section{Signatura}

HR-DAPA-474/6

\section{Naslov}

Ured za statistiku i evidenciju

\section{Vrijeme nastanka gradiva}

1952-1955

\section{Razina opisa}

Serija 


\section{Količina i zapis nosača}

$0,02 \mathrm{~d} / \mathrm{m}$

\section{Sadržaj}

Serija sadrži upute i okružnice koje se odnose na pravilno vođenje statistika i evidencija, nastale radom Ureda za statistiku i evidenciju. Serija također sadrži i formulare s raznim statističkim izvještajima.

\section{Plan sređivanja}

Gradivo je kronološki sređeno.

\section{Uvjeti dostupnosti i korištenja}

Gradivo serije javno je arhivsko gradivo i prema Zakonu o arhivskom gradivu i arhivima i Pravilniku o korištenju arhivskog gradiva u potpunosti je dostupno.

Inventarni popis gradiva serije

\begin{tabular}{|l|l|l|l|l|}
\hline Signatura & Naslov/sadržaj & $\begin{array}{l}\text { Raspon } \\
\text { godina }\end{array}$ & Tehnička jedinica & Napomena \\
\hline 6. & $\begin{array}{l}\text { Ured za statistiku i } \\
\text { evidenciju }\end{array}$ & $1952-1955$ & Kut. 4 & \\
\hline
\end{tabular}

\section{PROSVJETA I KULTURA}

\section{Signatura}

HR-DAPA-474/7

Naslov

Prosvjeta i kultura

\section{Vrijeme nastanka gradiva}

1952-1955

\section{Razina opisa}

Serija

Količina i zapis nosača

$0,03 \mathrm{~d} / \mathrm{m}$ 


\section{Sadržaj}

Serija sadrži spise koji se odnose na stanje u prosvjeti i kulturi u navedenom razdoblju. Gradivo serije odnosi se na upravljanje školama i školskom imovinom, problematiku nepohađanja nastave, upravljanje i osnivanje predškolskih ustanova, financiranje siromašnih učenika koji škole pohađaju u Italiji ili FNRJ, ali i onih koji školu pohađaju na području NOO-a, na prosvjetne radnike i djelatnike škola, na Narodnu tehniku i opismenjavanje. Jednako tako gradivo se odnosi i na upute, okružnice ili korespondenciju kulturnih društava s NOO-om. Ponajprije radi se o aktivnostima i financiranju kulturnih društava, podizanju spomenika, održavanju javnih plesova, prikupljanju kulturne baštine i upoznavanju NRH.

\section{Plan sređivanja}

Gradivo serije razvrstano je na dvije podserije: prosvjetu i kulturu, unutar kojih je, radi lakšega rukovanja i bolje preglednosti, razvrstano na podpodserije. Gradivo unutar podpodserija razvrstano je kronološki.

\section{Uvjeti dostupnosti i korištenja}

Dijelovi podserija 7.1.3. Učenici i 7.1.9. Dječji vrtići sadrže osobne podatke zbog čega su nedostupni do navedenih rokova.

Inventarni popis gradiva serije

\begin{tabular}{|c|c|c|c|c|}
\hline Signatura & Naslov/sadržaj & $\begin{array}{l}\text { Raspon } \\
\text { godina }\end{array}$ & $\begin{array}{l}\text { Tehnička } \\
\text { jedinica }\end{array}$ & Napomena \\
\hline \multicolumn{5}{|c|}{ 7. Prosvjeta i kultura 1952-1955 } \\
\hline 7.1. & Prosvjeta & $1952-1955$ & Kut. 4 & \\
\hline 7.1 .1$. & Politika i postupci & $1952-1955$ & Kut. 4 & \\
\hline 7.1 .2 . & $\begin{array}{l}\text { Školske zgrade } \\
\text { - sanacija } \\
\text { - inventari i primopredaja škola }\end{array}$ & $1952-1954$ & Kut. 4 & \\
\hline 7.1.3. & $\begin{array}{l}\text { Učenici } \\
\text { - Popis djece rođene 1946. i } 1947 . \\
\text { za upis u 1. razred 1953. } \\
\text { - Pomoć djeci palih boraca i žrtava } \\
\text { fašizma } \\
\text { - Nepohađanje nastave i kazne } \\
\text { roditeljima } \\
\text { - Molbe i rješenja u svezi s } \\
\text { oslobađanjem pohađanja nastave } \\
\text { - Pomoći za socijalno ugrožene } \\
\text { učenike }\end{array}$ & $1952-1955$ & Kut. 4 & $\begin{array}{l}\text { - Popis djece rođene } \\
\text { 1946. i } 1947 . \text { za upis } \\
\text { u 1. razred } 1953 \text {. } \\
\text { Nedostupno do } 2047 . \\
\text { - Pomoć djeci palih } \\
\text { boraca i žrtava } \\
\text { fašizma. Nedostupno } \\
\text { do } 2051 \text {. }\end{array}$ \\
\hline
\end{tabular}




\begin{tabular}{|c|c|c|c|c|}
\hline 7.1.4. & $\begin{array}{l}\text { Djelatnici } \\
\text { - premještaji, otkazi } \\
\text { - pomoći nastavnom osoblju i } \\
\text { njihovim obiteljima }\end{array}$ & $1952-1954$ & Kut. 4 & \\
\hline 7.1 .5 . & Obrtničke škole & 1952-1954 & Kut. 4 & \\
\hline 7.1.6. & Narodna tehnika & $1953 / 1955$ & Kut. 4 & \\
\hline 7.1 .7$. & Nepismenost & 1954 & Kut. 4 & \\
\hline 7.1 .8$. & Školski proračun & 1953-1955 & Kut. 4 & \\
\hline 7.1.9. & $\begin{array}{l}\text { Dječji vrtići } \\
\text { - popis djece koja će pohađati vrtić } \\
\text { - otvaranje dječjeg vrtića } \\
\text { - inventar }\end{array}$ & $1953-1954$ & Kut. 4 & $\begin{array}{l}\text { - Popis djece koja } \\
\text { će pohađati vrtić. } \\
\text { Nedostupno do } 2050 .\end{array}$ \\
\hline 7.2 . & Kultura & 1952-1955 & Kut. 4 & \\
\hline 7.2.1. & $\begin{array}{l}\text { Prikupljanje kulturne baštine i } \\
\text { upoznavanje NRH }\end{array}$ & $1952 / 1954$ & Kut. 4 & \\
\hline 7.2.2. & $\begin{array}{l}\text { Hrvatska prosvjetna društva } \\
\text { - Hrvatsko prosvjetno društvo } \\
\text { »Štrcaj Jordan« Poropati } \\
\text { - Hrvatsko prosvjetno društvo } \\
\text { »Iskra« Martinčići } \\
\text { - Hrvatsko prosvjetno društvo } \\
\text { »Matko Laginja« Grožnjan }\end{array}$ & $1953-1954$ & Kut. 4 & \\
\hline 7.2.3. & $\begin{array}{l}\text { Podizanje spomenika i obljetnice } \\
\text { oslobođenja }\end{array}$ & $1954-1955$ & Kut. 4 & \\
\hline 7.2.4. & Održavanje javnih plesova & 1952-1953 & Kut. 4 & \\
\hline
\end{tabular}

\section{NARODNO ZDRAVLJE I SOCIJALNA POLITIKA}

\section{Signatura}

HR-DAPA-474/8

\section{Naslov}

Narodno zdravlje i socijalna politika

\section{Vrijeme nastanka gradiva}

1952-1955

\section{Razina opisa}

Serija

\section{Količina i zapis nosača}

1 kutija, $0,1 \mathrm{~d} / \mathrm{m}$ 


\section{Sadržaj}

Serija sadrži razne uredbe, okružnice i upute u svezi s problematikom zbrinjavanja socijalno i zdravstveno ugroženoga dijela stanovništva. Posebno su zanimljivi spisi koji se odnose na pojavu prostitucije i maloljetničke delinkvencije.

\section{Plan sređivanja}

Gradivo serije podijeljeno je na dvije podserije: zdravstvo i socijalni odjel, unutar kojih je, radi preglednosti i lakšega rukovanja, raspoređeno na podpodserije. Gradivo unutar podpodserija razvrstano je kronološki.

\section{Uvjeti dostupnosti i korištenja}

Gradivo podserija 8.1.4. Cijepljenje djece, 8.1.6. Slanje djece u lječilišne kolonije i 8.2.10. Prostitucija sadrže osobne podatke kojima nije istekao rok čuvanja te su prema Zakonu o arhivskom gradivu i arhivima i Pravilniku o korištenju arhivskog gradiva nedostupni do navedenih datuma.

\section{Inventarni popis gradiva serije}

\begin{tabular}{|c|c|c|c|c|}
\hline Signatura & Naslov/sadržaj & $\begin{array}{l}\text { Raspon } \\
\text { godina }\end{array}$ & $\begin{array}{l}\text { Tehnička } \\
\text { jedinica }\end{array}$ & Napomena \\
\hline \multicolumn{5}{|c|}{ 8. Narodno zdravlje i socijalna politika 1952-1955 } \\
\hline 8.1. & Zdravstvo & 1952-1955 & Kut. 5 & \\
\hline 8.1.1. & Politika i postupci & 1952-1954 & Kut. 5 & \\
\hline 8.1.2. & Mrtvozorništvo & 1954 & Kut. 5 & \\
\hline 8.1.3. & Borba protiv TBC-a & 1953-1954 & Kut. 5 & \\
\hline 8.1.4. & Cijepljenje djece & 1953-1955 & Kut. 5 & $\begin{array}{l}\text { Nedostupno } \\
\text { do } 2053 \text {. }\end{array}$ \\
\hline 8.1.5. & Skrb za trudnice & 1952-1955 & Kut. 5 & \\
\hline 8.1.6. & Slanje djece u lječilišne kolonije & $1953-1955$ & Kut. 5 & $\begin{array}{l}\text { Nedostupno } \\
\text { do } 2047 .\end{array}$ \\
\hline 8.1.7. & Specijalistički pregledi & $1952 / 1955$ & Kut. 5 & \\
\hline 8.1 .8 . & Gluhe i gluhonijeme osobe & 1953-1954 & Kut. 5 & \\
\hline 8.2. & Socijalni odjel & 1952-1955 & Kut. 5 & \\
\hline 8.2 .1$. & Politika i postupci & $1952-1955$ & Kut. 5 & \\
\hline 8.2.2. & Izvještaji & 1955 & Kut. 5 & \\
\hline 8.2.3. & Tečajevi & 1954 & Kut. 5 & \\
\hline 8.2.4. & Crveni križ & 1953-1954 & Kut. 5 & \\
\hline 8.2.5. & $\begin{array}{l}\text { Pomoć socijalno ugroženima } \\
\text { - pomoći } \\
\text { - molba da Josip Broz Tito bude kum djetetu }\end{array}$ & $1952-1955$ & Kut. 5 & \\
\hline 8.2.6. & Nagrade majkama za $» 8$. mart« & 1954 & Kut. 5 & \\
\hline
\end{tabular}




\begin{tabular}{|l|l|l|l|l|}
\hline 8.2.7. & Dječji domovi & $1953-1955$ & Kut. 5 & \\
\hline 8.2.8. & Starateljski aktivi & $1953-1954$ & Kut. 5 & \\
\hline 8.2.9. & Dodjela skrbništva & $1953-1955$ & Kut. 5 & \\
\hline 8.2.10. & Prostitucija & $1953-1954$ & Kut. 5 & $\begin{array}{l}\text { Nedostupno } \\
\text { do 2038. }\end{array}$ \\
\hline 8.2.11. & Maloljetnička delinkvencija & 1953 & Kut. 5 & \\
\hline 8.2 .12$. & Nezaposlenost & $1952-1954$ & Kut. 5 & \\
\hline 8.2.13. & Invalidnine & $1952-1954$ & Kut. 5 & \\
\hline 8.2 .14$. & Mirovine & $1952 / 1955$ & Kut. 5 & \\
\hline 8.2 .15$. & Starački domovi & $1953-1954$ & Kut. 5 & \\
\hline 8.2.16. & Udruga slijepih & $1953-1954$ & Kut. 5 & \\
\hline
\end{tabular}

\section{PRIVREDA I KOMUNALNI POSLOVI}

\section{Signatura}

HR-DAPA-474/9

\section{Naslov}

Privreda i komunalni poslovi

\section{Vrijeme nastanka gradiva}

1952-1955

\section{Razina opisa}

Serija

\section{Količina i zapis nosača}

2 kutije, $0,2 \mathrm{~d} / \mathrm{m}$

\section{Sadržaj}

Serija sadrži spise koji se odnose na upravljanje privredom. Tome pripadaju propisi i upute za rad obrtnika, registraciju obrtničkih radnji, izvještaji o poljoprivrednoj proizvodnji, poljoprivrednim štetama, naredbe i upute koje se odnose na iskorištavanje šuma, zaštitu šuma i pošumljavanje, upute i okružnice koje se odnose na trgovačku i ugostiteljsku djelatnost, pravila o radu zadruga, rješenja o podizanju i popravku raznih objekata, uredbe i pravila obilježavanja kućnih brojeva, imenovanja ulica i trgova te drugi spisi koji pripadaju komunalnoj i privrednoj djelatnosti. 


\section{Plan sređivanja}

Gradivo serije podijeljeno je na dvije podserije: komunalni poslovi i privreda, unutar kojih je, radi preglednosti i lakšega rukovanja, gradivo raspoređeno na podpodserije ili još niže razine. Gradivo unutar podpodserija i još nižih razina razvrstano je kronološki.

\section{Uvjeti dostupnosti i korištenja}

Dijelovi podserije 9.1.6.2 Imovina optanata sadrže osobne podatke kojima nije istekao rok čuvanja te su prema Zakonu o arhivskom gradivu i arhivima i Pravilniku o korištenju arhivskog gradiva nedostupni do navedenog datuma.

Inventarni popis gradiva serije

\begin{tabular}{|c|c|c|c|c|}
\hline Signatura & Naslov/sadržaj & Raspon godina & $\begin{array}{l}\text { Tehnička } \\
\text { jedinica }\end{array}$ & Napomena \\
\hline \multicolumn{5}{|c|}{ 9. Privreda i komunalni poslovi $1952-1955$} \\
\hline 9.1. & Komunalni poslovi & 1952-1955 & Kut. 6 & \\
\hline 9.1.1. & Politika i postupci & $1952-1955$ & Kut. 6 & \\
\hline 9.1.2. & $\begin{array}{l}\text { Imenovanje mjesta, ulica, } \\
\text { trgova }\end{array}$ & 1954 & Kut. 6 & \\
\hline 9.1.3. & $\begin{array}{l}\text { Dodjela kućnih brojeva, } \\
\text { popis naselja i popisnih } \\
\text { krugova NOO-a Grožnjan } \\
\text { - elaborat } \\
\text { - katastarske mape s } \\
\text { upisanim brojevima zgrada } \\
\text { (crtano rukom) }\end{array}$ & 1953 & Kut. 6 & \\
\hline 9.1.4. & Elektrifikacija & $1952-1955$ & Kut. 6 & \\
\hline 9.1.5. & Vodoprivreda & 1953-1955 & Kut. 6 & \\
\hline 9.1.5.1. & Politika i postupci & 1954 & Kut. 6 & \\
\hline 9.1.5.2. & Vodna zajednica & $1953-1955$ & Kut. 6 & \\
\hline 9.1.5.3. & Zaštita od poplava & 1955 & Kut. 6 & \\
\hline 9.1.5.4. & Opskrba vodom & $1953-1955$ & Kut. 6 & \\
\hline 9.1.5.5. & Melioracija & 1953-1954 & Kut. 6 & \\
\hline 9.1.6. & Imovina & $1952-1955$ & Kut. 6 & \\
\hline 9.1.6.1. & Politika i postupci & $1952-1955$ & Kut. 6 & \\
\hline 9.1.6.2. & Imovina optanata & 1955 & Kut. 6 & $\begin{array}{l}\text { Nedostupno do } \\
2033 \text {. }\end{array}$ \\
\hline 9.1.6.3. & Konfiskacija imovine & [1951] 1952-1954 & Kut. 6 & \\
\hline 9.1.6.4. & $\begin{array}{l}\text { Konfiskacija crkvene } \\
\text { imovine }\end{array}$ & 1954 & Kut. 6 & \\
\hline 9.1.6.5. & $\begin{array}{l}\text { Upravljanje napuštenom } \\
\text { imovinom }\end{array}$ & $1952-1955$ & Kut. 6 & \\
\hline 9.1.6.6. & Imovinsko-pravni odnosi & [1951] 1952-1955 & Kut. 6 & \\
\hline
\end{tabular}




\begin{tabular}{|c|c|c|c|}
\hline 9.1.6.7. & $\begin{array}{l}\text { Popis imovine bivše } \\
\text { države, odsutnih osoba i } \\
\text { općenarodne imovine }\end{array}$ & $1952-1953$ & Kut. 6 \\
\hline 9.1.6.8. & Općenarodna imovina & $1952-1955$ & Kut. 6 \\
\hline 9.1.7. & Gradnja & $1952-1955$ & Kut. 7 \\
\hline 9.1.7.1. & $\begin{array}{l}\text { Statistika građevinskih } \\
\text { radova }\end{array}$ & $1952 / 1954$ & Kut. 7 \\
\hline 9.1.7.2. & Građevinske dozvole & 1952-1954 & Kut. 7 \\
\hline 9.1.7.3. & $\begin{array}{l}\text { Obnova uništenih i } \\
\text { dotrajalih objekata i kuća }\end{array}$ & $1952-1955$ & Kut. 7 \\
\hline 9.1.7.4. & Kino dvorana & 1953 & Kut. 7 \\
\hline 9.1.7.5. & Zgrada pošte & 1953 & Kut. 7 \\
\hline 9.1.7.6. & Lovački dom & 1953 & Kut. 7 \\
\hline 9.1.7.7. & Zgrade kulture & $1953 / 1955$ & Kut. 7 \\
\hline 9.1.7.8. & Gradnja gnojnica & 1955 & Kut. 7 \\
\hline 9.1 .8$. & Stambena pitanja & $1952-1955$ & Kut. 7 \\
\hline 9.1.9. & Dimnjačarska služba & 1953 & Kut. 7 \\
\hline 9.1.10. & Cestovna služba & $1952-1955$ & Kut. 7 \\
\hline 9.1.11. & Autobusni promet & 1952-1954 & Kut. 7 \\
\hline 9.2. & Privreda & $1952-1955$ & Kut. 7 \\
\hline 9.2.1. & Politika i postupci & 1953-1955 & Kut. 7 \\
\hline 9.2.2. & Ugostiteljstvo & 1953-1955 & Kut. 7 \\
\hline 9.2.3. & Zanatska djelatnost & $1952-1955$ & Kut. 7 \\
\hline 9.2.4. & $\begin{array}{l}\text { Proizvodnja i prodaja } \\
\text { alkohola }\end{array}$ & $1952-1955$ & Kut. 7 \\
\hline 9.2 .5 & Standardizacija mjera & $1952 / 1955$ & Kut. 7 \\
\hline 9.2.6. & Trgovina & $1952-1955$ & Kut. 7 \\
\hline 9.2.7. & Držanje pasa & 1952-1954 & Kut. 7 \\
\hline 9.2.8. & Poljoprivreda & $1952-1955$ & Kut. 7 \\
\hline 9.2.8.1. & $\begin{array}{l}\text { Seljačka radna zadruga } \\
\text { »Sloboda« Krasica }\end{array}$ & $1953-1955$ & Kut. 7 \\
\hline 9.2.8.2. & $\begin{array}{l}\text { Nagrade } \\
\text { poljoprivrednicima }\end{array}$ & $1952-1954$ & Kut. 7 \\
\hline 9.2.8.3. & Meljava pšenice & 1953-1955 & Kut. 7 \\
\hline 9.2.8.4 & $\begin{array}{l}\text { Komisija za procjenu } \\
\text { priroda }\end{array}$ & $1952-1955$ & Kut. 7 \\
\hline 9.2.8.5. & Komisija za procjenu štete & 1953-1955 & Kut. 7 \\
\hline 9.2.8.6. & Povrede imovine & $1952-1955$ & Kut. 7 \\
\hline 9.2.8.7. & Suzbijanje štetnika & 1952-1954 & Kut. 7 \\
\hline 9.2.8.8. & $\begin{array}{l}\text { Suzbijanje životinjskih } \\
\text { bolesti }\end{array}$ & 1953-1955 & Kut. 7 \\
\hline 9.2.8.9. & $\begin{array}{l}\text { Proizvodnja maslinovog } \\
\text { ulja }\end{array}$ & $1952-1954$ & Kut. 7 \\
\hline 9.2.8.10. & Uzgoj domaćih životinja & 1953-1955 & Kut. 7 \\
\hline 9.2.8.11. & Šumarstvo & $1952-1955$ & Kut. 7 \\
\hline
\end{tabular}




\begin{tabular}{|l|l|l|l|l|}
\hline 9.2 .8 .12$. & Lov & $1952 / 1954$ & Kut. 7 & \\
\hline 9.2 .8 .13$. & Pašnjaci & $1952 / 1955$ & Kut. 7 & \\
\hline 9.2 .8 .14$. & Klizišta & 1953 & Kut. 7 & \\
\hline 9.2 .9$. & Dozvole za uvoz/izvoz & $1952-1955$ & Kut. 7 & \\
\hline
\end{tabular}

\section{FINANCIJE}

\section{Signatura}

HR-DAPA-474/10

\section{Naslov}

Financije

\section{Vrijeme nastanka gradiva}

1952-1955

\section{Razina opisa}

Serija

\section{Količina i zapis nosača}

$1 \mathrm{kutija}, 0,1 \mathrm{~d} / \mathrm{m}$

\section{Sadržaj}

Serija sadrži spise koji se odnose na financijsko poslovanje NOO-a Grožnjan.

\section{Plan sređivanja}

Gradivo serije podijeljeno je na podserije, unutar kojih je kronološki sređeno.

\section{Uvjeti dostupnosti i korištenja}

Gradivo serije javno je arhivsko gradivo i prema Zakonu o arhivskom gradivu i arhivima i Pravilniku o korištenju arhivskog gradiva u potpunosti je dostupno.

\section{Inventarni popis gradiva serije}

\begin{tabular}{|l|l|l|l|l|}
\hline Signatura & Naslov/sadržaj & Raspon godina & $\begin{array}{l}\text { Tehnička } \\
\text { jedinica }\end{array}$ & Napomena \\
\hline \multicolumn{5}{|l|}{} \\
\hline 10. Financije 1952-1955 \\
\hline \multicolumn{5}{|l|}{} \\
\hline 10.1. & Politika i postupci & $1952-1955$ & Kut. 8 & \\
\hline 10.2. & Planovi & $1952-1955$ & Kut. 8 & \\
\hline 10.3. & Završni račun & $1952-1954$ & Kut. 8 & \\
\hline 10.4. & Isplatne liste & $1952-1955$ & Kut. 8 & $\begin{array}{l}\text { Čuvati do 2022-2025., } \\
\text { nakon toga izlučiti }\end{array}$ \\
\hline
\end{tabular}




\section{SAŽETAK}

\section{Sumarni inventar fonda HR-DAPA-474 Narodni odbor općine Grožnjan (Comitato popolare comunale Grisignana) [1951] 1952-1955}

Narodni odbor općine Grožnjan djeluje u razdoblju 1952. - 1955., kao upravno tijelo unutar svoje nadležnosti. Kao izvršni organ vlasti osiguravao je i provodio nesmetan razvoj privrede, komunalnih poslova, trgovine, financija, zdravstvene, socijalne skrbi, sudstva itd. Unutar NOO-a djelovala je i matičarska služba koje je vodila evidencije stanovništva. Izvršni odbor NOO-a na svojim je sjednicama raspravljao o aktualnim pitanjima i problemima te je donosio rješenja i odluke koji su omogućavali daljnji razvoj zajednice. Promjenom zakona i prestankom postojanja NOO-a Grožnjan, gradivo fonda preuzeo je sljednik, NOO Buje. Od NOO-a Buje preuzela ga je Skupština općine Buje, od koje ga je, pak, 1977. preuzeo Historijski arhiv - Pazin, danas Državni arhiv u Pazinu. Arhivistička obrada fonda napravljena je 2018. godine. Gradivo fonda podijeljeno je u 10 serija: Zapisnici i materijali izvršnih, pomoćnih i nadzornih tijela NOO-a, Opće administrativno poslovanje, Unutrašnji poslovi, Vojni odjel, Pravosuđe, Ured za statistiku i evidenciju, Prosvjeta i kultura, Narodno zdravlje i socijalna politika, Privreda i komunalni poslovi i Financije.

\section{SUMMARY}

\section{Summary inventory of the Fonds HR-DAPA-474 People's Committee of the Municipality of Grožnjan (Comitato popolare comunale Grisignana) [1951] 1952-1955}

The People's Committee of the Municipality of Grožnjan operated from 1952 to 1955 as an administrative body within its jurisdiction. As an executive body, it ensured and implemented the smooth development of the economy, municipal tasks, commerce, finance, health, social care, judiciary, etc. The People's Committee comprised also a registry service that kept population records. At its sessions, the Executive Board of the People's Committee discussed current issues and problems and passed resolutions and decisions that allowed for further development of the community. Following the change of the law and the termination of the existence of the People's Committee of the Municipality of Grožnjan, the archives of the Fonds was taken over by the successor, the People's Committee of the Municipality of Buje. It was then taken over from the People's Committee of the Municipality of Buje by the Municipal Assembly of Buje, from which, in 1977, it was taken over by the Historical Archives of Pazin, today's State Archives in Pazin. The archival processing of the Fonds was made in 2018. The material of the Fonds is divided into 10 series: Minutes and materials of executive, support and supervisory bodies of the People's Committee, General administrative operations, Internal affairs, Military department, Judiciary, Statistics and records office, Education and culture, National health and social policy, Economy and municipal affairs and Finance. 


\section{RIASSUNTO}

\section{Inventario sommario del fondo HR-DAPA-474 Comitato popolare comunale Grisignana [1951] 1952-1955}

Il Comitato popolare comunale di Grisignana opera nel periodo dal 1952 al 1955 come organo amministrativo nell'ambito delle sue competenze. In quanto organo del potere esecutivo assicurava ed eseguiva la continuità nello sviluppo dell'economia, lavori comunali, commercio, finanze, servizi sanitari e sociali, magistratura, ecc. Inoltre, all'interno del Comitato popolare comunale operava l'ufficio anagrafe che registrava dati relativi alla popolazione. Il comitato esecutivo del Comitato popolare comunale nelle proprie sedute discuteva di questioni e problemi attuali e adottava decisioni che permettevano lo sviluppo ulteriore della comunità. Con il cambiamento della legge e la cessazione del Comitato popolare comunale di Grisignana, il materiale del Fondo è passato al successore, al Comitato popolare di Buie. Dal Comitato popolare comunale di Buie poi all'Assemblea del comune di Buie da cui in seguito, nel 1977, è passato all'Archivio storico - Pazin/Pisino, oggi Archivio di Stato di Pisino. Il trattamento archivistico del Fondo è stato effettuato nel 2018. Il materiale del Fondo è diviso in 10 serie: Verbali e materiali degli organi esecutivi, ausiliari e di vigilanza del Comitato popolare comunale, Attività amministrativa generale, Affari interni, Dipartimento militare, Magistratura, Ufficio per la statistica e le registrazioni, Istruzione e cultura, Sanità popolare e politiche sociali, Economia e lavori comunali e Finanze. 